\title{
DNA SEQUENCE POLYMORPHISMS IN THE GENUS SACCHAROMYCES III. RESTRICTION ENDONUCLEASE FRAGMENT PATTERNS OF CHROMOSOMAL REGIONS IN BREWING AND OTHER YEAST STRAINS
}

\author{
by \\ MOGENS BOHL PEDERSEN
}

Department of Brewing Chemistry, Carlsberg Research Laboratory, Gamle Carlsberg Vej 10, DK-2500 Copenhagen Valby
Keywords: Bottom fermenting, top fermenting, DNA hybridization, OFAGE, S. bayanus, S. capensis, S. carlsbergensis, S. cerevisiae, S. chevalieri, S. diastaticus, S. ellipsoideus, S. inusitatus, S. italicus, S. monacensis, S. norbensis, S. pastorianus, S. uvarum, Zygosaccharomyces fermentati, taxonomy

\begin{abstract}
30 bottom fermenting strains, 13 hybrid lager strains, 11 top fermenting strains. In addition, 24 other yeast species and strains have been analysed in this study. Four DNA regions have been monitored by restriction endonuclease fragment pattern polymorphisms. The regions analysed are: $R D N I$ (encoding cytosolic ribosomal RNA molecules) located on chromosome XII in S. cerevisiae, HIS4 (histidine 4) and LEU2 (leucine 2) both located on chromosome III and the $T y$ elements which are distributed at different positions in the genome of S. cerevisiae. Seven $T y$ fragment patterns have been detected in the bottom fermenting strains. Patterns I, II, IIa, IIb, and IIc are present in lager strains while pattern III and IV are found in S. carlsbergensis bottom fermenting strain No. I and in S. monacensis, respectively. Hybridization of the $T y l$ p14 probe from S. cerevisiae to OFAGE separated chromosomes from bottom fermenting strains show that at least five $T y$ elements are present in the genomes of the lager strains, at least five in S. carlsbergensis bottom fermenting strain No. I and at least three in S. monacensis. From the restriction fragment patterns and the karyotypes of the bottom fermenting strains it is suggested that these strains are closely related and different from the $\mathbf{S}$. bayanus, $\mathbf{S}$. pastorianus, and $\mathbf{S}$. uvarum group as well as from the $\mathbf{S}$. cerevisiae strains. In spite of their differences in $T y$ element patterns the lager strains are so homogenous that most likely they all originate from a single strain which is related to $S$. carlsbergensis and $S$. monacensis type strains. In contrast to the bottom fermenting strains there is a large variability among the top fermenting strains, especially with regard to the $L E U 2$ gene and $T y$ elements. It seems that $\mathrm{S}$. bayanus, $\mathrm{S}$. inusitatus, $\mathrm{S}$. pastorianus, $\mathrm{S}$. validus, and $\mathrm{S}$. uvarum are closely related, and none of the studied strains from these taxons contained DNA which hybridized to the $T y l$ probe from S. cerevisiae. This is a clear difference from the DNA of bottom fermenting strains which consistently hybridized strongly to the $T y l$ probe.
\end{abstract}

Abbreviations: $\mathrm{kb}=$ kilo base pairs; OFAGE = orthogonal field alternation gel electrophoresis; $\mathrm{SSC}=0.15 \mathrm{M}-\mathrm{NaCl}$, $15 \mathrm{mM}-\mathrm{Na}$ citrate; TBE $=0.089 \mathrm{M}$-Tris-borate, $0.089 \mathrm{M}$-boric acid, $0.002 \mathrm{M}$-EDTA; Tris = tris-(hydroxymethyl)amino methane 


\section{INTRODUCTION}

Several methods have been employed for taxonomic studies of yeast strains. These comprise analyses of morphological and physiological characters, of isoenzymes (64), serologically distinguishable components $(1,37)$ and nucleic acids (66). Yeast nucleic acids have been characterised in several ways including the determination of base composition $(49,51,66)$, DNA - RNA homologies and DNA - DNA reassociations kinetics $(4,8,32,36,51)$. In recent years restriction endonuclease fragment pattern polymorphisms (RFLPs) of several DNA regions have proven to be very useful for differentiation of yeast strains $(2,10,13,16,18,19,20$, $27,30,35,39,40,41,42,43,44,45,48,55)$. In the present study four DNA regions have been screened, namely: $R D N I(7,15,47)$ on chromosome XII (46), HIS4 (21, 26, 27) and LEU2 (3, $5,14,22,30,59)$ genes on chromosome III (38), and the Ty element regions homologous to $T y l$ from $S$. cerevisiae genetic standard strains (19, $20,48) . R D N I$ encodes the $18 \mathrm{~S}, 5.8 \mathrm{~S}, 25 \mathrm{~S}$, and $5 \mathrm{~S}$ cytosolic ribosomal RNA molecules $(7,47$, 54). At least three forms of the $R D N 1$ gene cluster exist in the genus, namely forms I, II (7, $15)$, and III $(40,41)$. The HIS4 gene is located together with $L E U 2$ on the left arm of chromosome III (38). The HIS4 locus encodes steps 3, 2, and 10 in the histidine de novo biosynthesis (21). Three restriction pattern alleles of this gene have been detected in the genus, I, II $(26,27,39)$, and III (4I). The $L E U 2$ gene encoding the beta-isopropylmalate dehydrogenase $(3,5)$ is positioned on chromosome III in the genetic standard strain S. cerevisiae S288C $(14,38)$. For classification purposes the variety of $L E U 2$ Sall fragment sizes has been especially helpful, since by coincidence each fragment behaves as an allele of $L E U 2$ (30, $43,44)$. Seven $T y$ restriction fragment patterns have been detected in bottom fermenting (lager) strains by hybridization with the $T y l$ probe (43 and this paper). In an early study polymorphism was not reported for hybridization with the $T y 1$ p29 probe containing the "left" portion of $T y 1$ from S. cerevisiae (2). Additional European bottom fermenting strains studied $(16,35)$ seem to contain restriction fragment patterns comparable to those detected in the Danish and Bavarian strains (43). The genomic location of the varying restriction endonuclease fragments had to be determined. Localisation of Ty elements in S. cerevisiae has been accomplished by genetic mapping (31). In the present study the $T y$ elements in bottom fermenting strains have been localized on certain chromosomes by electrophoretic separation of the intact DNA molecules of the chromosomes by orthogonal field alternation gel electrophoresis (OFAGE) and molecular hybridization of the $T y$ probe to the separated chromosomes. The Tyelements in the bottom fermenting strains studied are located in the same five chromosomal bands.

By electrophoretic separation of single chromosomes and molecular hybridization of radioactively labelled probes the physical and genetic maps of the $\mathrm{S}$. cerevisiae genome have been aligned $(11,12,53)$. Analyses of chromosome III in bottom fermenting and other Saccharomyces strains by single chromosome transfer followed by electrophoretic karyotyping and molecular hybridization with radioactively labelled probes are reported in the accompanying paper (44).

An overview of the restriction endonuclease fragment polymorphisms in relation to the different taxons studied is presented in Figure 1.

\section{MATERIALS AND METHODS}

\subsection{Strains and growth medium}

Yeast strains used in this study are referenced in Tables I, II, III, and IV. In Table I are listed the bottom fermenting strains which in a previous paper have been analysed at the $R D N 1$ and $H I S 4$ genes (41). Table II contains hybrid lager strains which have been selected by C. GJERMANSEN from crosses of spore clones (23) derived from the Carlsberg and Tuborg brewing strains. Top fermenting strains are listed in Table III. In Table IV are tabulated type strains of different species and wild yeast strains which have been compared with regard to the RDN1, HIS4, and $L E U 2$ genes as well as the $T y$ elements. All strains were grown on YPD, complete medium according to SHERMAN, FINK, and HICKS (56).

\subsection{Preparation of DNA and molecular hybridization analyses \\ Isolation of yeast total DNA was done accord- ing to PEDERSEN (43) and E. coli plasmid DNAs}




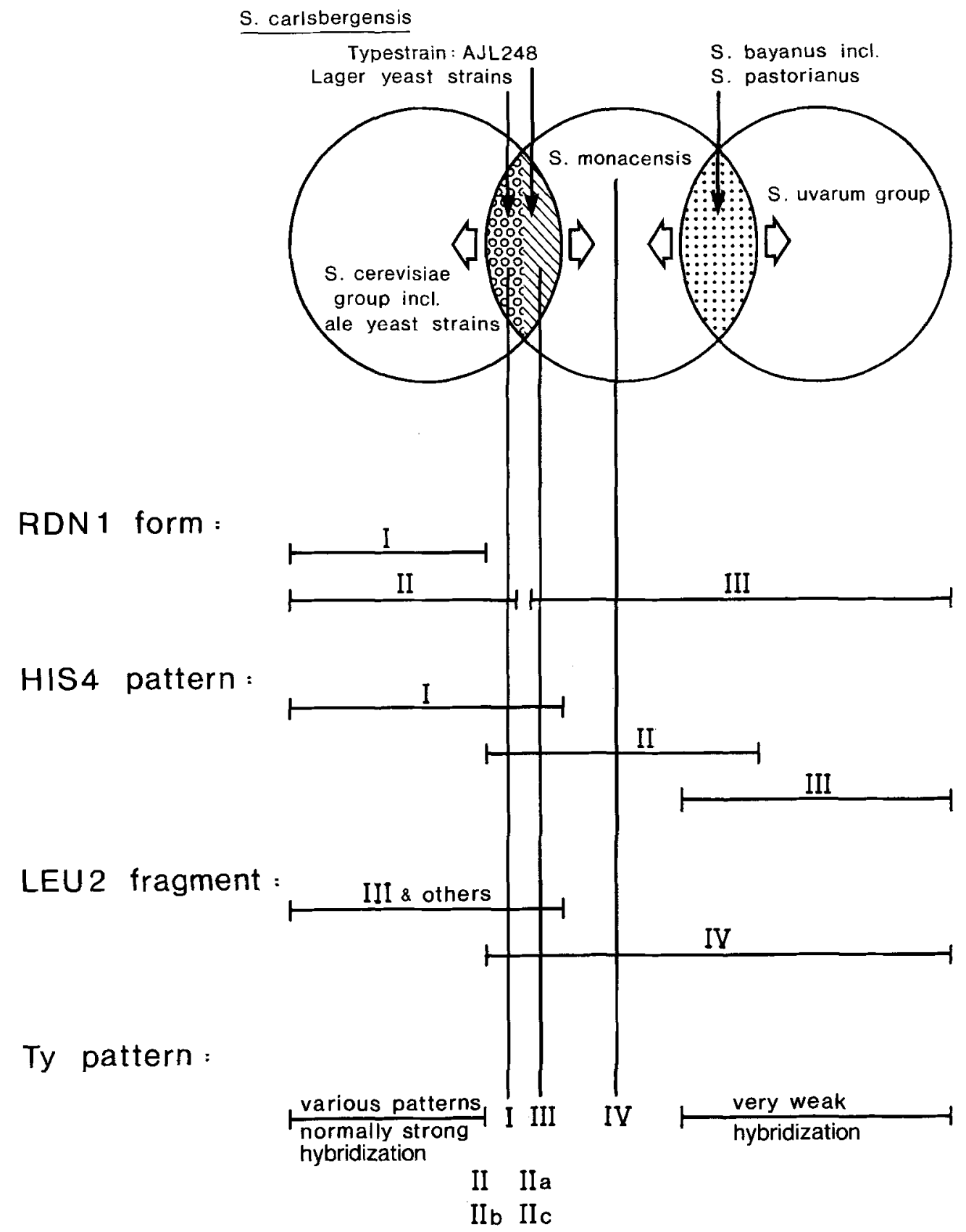

Figure 1. Composite diagram of the restriction endonuclease fragment length polymorphisms (RFLPs) observed in this and previous studies $(39,40,41,42,43)$. The roman numerals above the horizontal bars correspond to the allele of the particular gene or region. RDN1: The gene encoding cytosolic ribosomal RNA, HIS4: the region covering the HIS4 gene located on chromosome III, LEU2: Sall fragment pattern of the LEU2 gene located on chromosome III, Ty: The pattern of fragments hybridizing to the $T y 1$ p14 probe from S. cerevisiae. 
were isolated in preparative scale as described by Holmes and Quigley (28). Transfer of DNA to nitrocellulose was done by the procedure of Southern (58) as described in (34). Molecular hybridization of radioactively labelled probes to DNA affixed to nitrocellulose filters was carried out according to DENHARDT (17) with the modifications introduced by JEFFREYS and FLAVELL (29). The probes were labelled with $\left(\alpha-{ }^{32}\right.$ P)dATP (NEG 012A, New England Nuclear) by nick translation according to RIGBY et al. (50). Restriction endonucleases were obtained from Boehringer Mannheim and were used according to MANIATIS. FRITCH, and SAMBROOK (34). Autoradiographs were exposed at $-80^{\circ} \mathrm{C}$ with Kodak X-Omatic screens on Kodak XRPI or XAR5 films.

\subsection{Probes}

Four probes have been used in this study : a) pY 1 rA 12 containing the RDN1 form II gene from $\mathrm{S}$. cerevisiae (45), b) pC503 containing the $9.4 \mathrm{~kb}$ Pstl insert covering the HIS4 gene from S. cerevisiae (26), c) pC512 with an Sall-Sall fragment containing the $L E U 2$ coding region ( 27 , $30,43,59)$, and d) p14 containing a $1.5 \mathrm{~kb}$ Sall-EcoRI fragment of the $T y /$ element from $\mathrm{S}$. cerevisiae (48). Only the $0.9 \mathrm{~kb}$ EcoRI-Sall fragment covering the 3 ' end of the $L E U 2$ coding region has been used as a $L E U 2$ probe. The LEU2 EcoRI-Sall fragment was isolated and purified from agarose gels according to Y $\mathrm{ANG}$, LIS. and Wu (65).

\subsection{Preparation of yeast DNA for electrophoretic karyotyping (OFAGE)}

The isolation of chromosomal sized DNA molecules was performed by modification of the method by SCHWARTZ and CANTOR (53). Freshly grown cells in an amount corresponding to $100-150 \mu \mathrm{l}$ were scraped off a YPD plate and transferred to a $1.5 \mathrm{ml}$ Eppendorf tube. The cells were suspended in $1 \mathrm{ml}$ of $50 \mathrm{mM}$-EDTA +10 $\mathrm{mM}$-Tris pH 7.5, spun down and resuspended twice. After a second wash the cells were spun down and resuspended in $150 \mu \mathrm{l}$ of the above medium and $10 \mu \mathrm{l}$ of zymolyase added (20 $\mathrm{mg} / \mathrm{ml}$ zymolyase in $10 \mathrm{mM}$-sodium phosphate
$\mathrm{pH} 7.5)$. After mixing $250 \mu \mathrm{l}$ of $1 \mathrm{M}$-dithiotreitol was added together with $400 \mu \mathrm{l}$ of $1 \%$ low melting point agarose in $0.125 \mathrm{M}-\mathrm{EDTA}, \mathrm{pH}$ $7.5,38^{\circ} \mathrm{C}$. All was mixed carefully and immediately put on ice. After hardening of the agarose plug $500 \mu \mathrm{l}$ of LET buffer (0.5 M-EDTA, 10 $\mathrm{mM}$-Tris. $\mathrm{pH} 7.5$ ) was added as an overlayer and the Eppendorf tubes were incubated overnight at $37{ }^{\circ} \mathrm{C}$. After incubation the overlayer was removed and replaced by $500 \mu \mathrm{l}$ of NDS buffer (LET + 1\% N-lauroyl-sarcosine, $\mathrm{pH} 9.5+0.5 \mathrm{mg}$ proteinase $\mathrm{K}$ ) and incubated overnight at $50^{\circ} \mathrm{C}$. The following day the NDS buffer was removed and the agar plugs were rinsed for $4 \times 1$ hour in $1 \mathrm{ml}$ of I.ET buffer. The preparations are stored at $4{ }^{\circ} \mathrm{C}$ in LET buffer. Before the analysis appropriate samples of the agar plugs (a size of 50 $\mu \mathrm{l})$ are cut out of the plug and rinsed in $1 \mathrm{ml}$ of $50 \mathrm{mM}$-EDTA + $10 \mathrm{mM}$-Tris $\mathrm{pH} 7.5$ for 1 hour in an Eppendorf tube. After incubation the buffer is removed and the tube is transferred to a heat block and incubated at $70{ }^{\circ} \mathrm{C}$ for 10 minutes to melt the agarose.

The OFAGE apperatus used in this study is of the type described by CARLE and OLSON (11). Eleven samples of $20 \mu \mathrm{I}$ DNA were loaded into slots of a $1 \%$ agarose gel made up with $0.5 \times \mathrm{J}$ BE buffer. Electrophoresis was in 31 of $0.5 \times \mathrm{T} B \mathrm{BE}$ buffer at $200 \mathrm{~mA}$ constant current and with a pulse period of 50 seconds. The electrophoresis was performed for $15-18$ hours at $8-12{ }^{\circ} \mathrm{C}$. The gel was subsequently stained in $1 \mu \mathrm{g} / \mathrm{ml}$ ethidium bromide for 2 hours and destained for at least 4 hours prior to analysis. Southern transfer of chromosomal DNA and molecular hybridization of nick translated probes were performed as described in 2.2 .

\section{RESULTS}

\subsection{Molecular hybridization studies of DNA from bottom fermenting strains}

\subsubsection{LEU2 restriction endonuclease fragment monomorphism}

Is has previously been reported $(40,41)$ that with one exception the bottom fermenting strains listed in Table I were identical and thus indistinguishable when the DNA was digested with restriction endonucleases, the fragments electrophoretically separated and analysed for 
Table I. Restriction endonuclease fragment patterns in bottom fermenting strains designated as Saccharomyces carlsbergensis, previously analysed at the RDN1 and HIS4 genes (cf. (41, Table I and Figure 6, lanes j-p)). LEU2 fragments: Sall restriction endonuclease fragments (43, Figure 2) hybridizing to the EcoRI-SalI part of the $L E U 2$ gene from S. cerevisiae strain S288C. Ty pattern: Patterns of restriction endonuclease fragments (Figure 2) hybridizing to the $T y l$ transposable element p14 probe.

\begin{tabular}{llll}
\hline Strain: & $\begin{array}{l}\text { LEU2 } \\
\text { fragments }\end{array}$ & $\begin{array}{l}\text { Ty } \\
\text { patterns }\end{array}$ & Source: \\
\hline BK1101 & III+IV & IIa & Germany, PSCHORR 1939 \\
BK1103 & III+IV & I & Denmark, Carlsberg 1964 \\
BK1111 & III+IV & IIb & Germany, WEIHENSTEPHAN 1966 \\
BK1112 & III+IV & I & Denmark, Alfr. Jørgensen No.2190 \\
BK1115 & III+IV & I & USA, ScHAEFRS, New York 1947 \\
BK2224 & III+IV & II & Tuborg lager strain \\
BK2229 & III+IV & II & Denmark, Alfr. Jørgensen No.1522 \\
BK2231 & III+IV & I & Sweden, Lyckholm Bryg. \\
BK2236 & III+IV & IIc & Denmark, \\
BK2246 & III+IV & I & Carisberg lager strain \\
C82-FP2 & III+IV & I & Malta \\
C82-FP3 & III+IV & I & Italy \\
C82-FP4 & III+IV & I & Cameroun \\
C82-FP6 & III+IV & I & France \\
C82-FP7 & III+IV & I & Portugal \\
C82-FP9 & III+IV & I & Canada \\
C82-FP11 & III+IV & I & Norway \\
C82-FP20 & III+IV & I & Cameroun \\
C82-FP21 & III+IV & I & Puerto Rico \\
C82-FP5 & III+IV & IIa & Norway \\
C82-FP8 & III+IV & Ila & Portugal \\
C82-FP14 & III+IV & IIa & Portugal \\
C82-FP19 & III+IV & IIa & Cameroun \\
C82-FP22 & III+IV & IIa & Sweden \\
C82-FP26 & III+IV & IIa & Eire \\
C83-FP34 & III+IV & IIb & Germany \\
C83-FP35 & III+IV & I & Germany \\
C83-FP36 & III+IV & IIa & Germany \\
\hline & & &
\end{tabular}

the RDNI and HIS4 genes. The exception is the Pschorrstrain which presumably is homozygous for one of the two allelic HIS4 regions present in lager strains. As evident from Table I the $L E U 2$ locus is monomorphic in all bottom fermenting strains including the Pschorr lager strain since the $L E U 2$ probe hybridizes to the same SalI restriction fragments III of $\sim 16 \mathrm{~kb}$ and IV of $12 \mathrm{~kb}((42,43)$. Hybridization of the LEU2 probe to EcoRI and Sall double digested DNA from bottom fermenting strains show that they contain a $0.9 \mathrm{~kb}$ fragment of the same size as the probe, which indicates that no sequence variation is present in the 3' end of the LEU2 coding region.

\subsubsection{Ty pattern analysis}

The patterns of the restriction endonuclease fragments hybridizing to the labelled $T y$ element sequence in Southern blots of EcoRI and SalI digested DNA of bottom fermenting strains reveal considerable similarity (Figure 2 ). The Carlsberg lager strain (pattern I) lacks a ca. 5.5. $\mathrm{kb}$ EcoRI fragment and a similar sized SalI fragment carrying a $T y$ element when compared to the Tuborg lager strain (pattern II) as shown in Figure 2, lanes a and $b$. The pattern I was found in 15 strains and pattern II in 2 strains (Table I). This latter pattern occurs additionally in three variant forms. In pattern IIa the $5.5 \mathrm{~kb}$ EcoRI and SalI fragments hybridize less intense- 


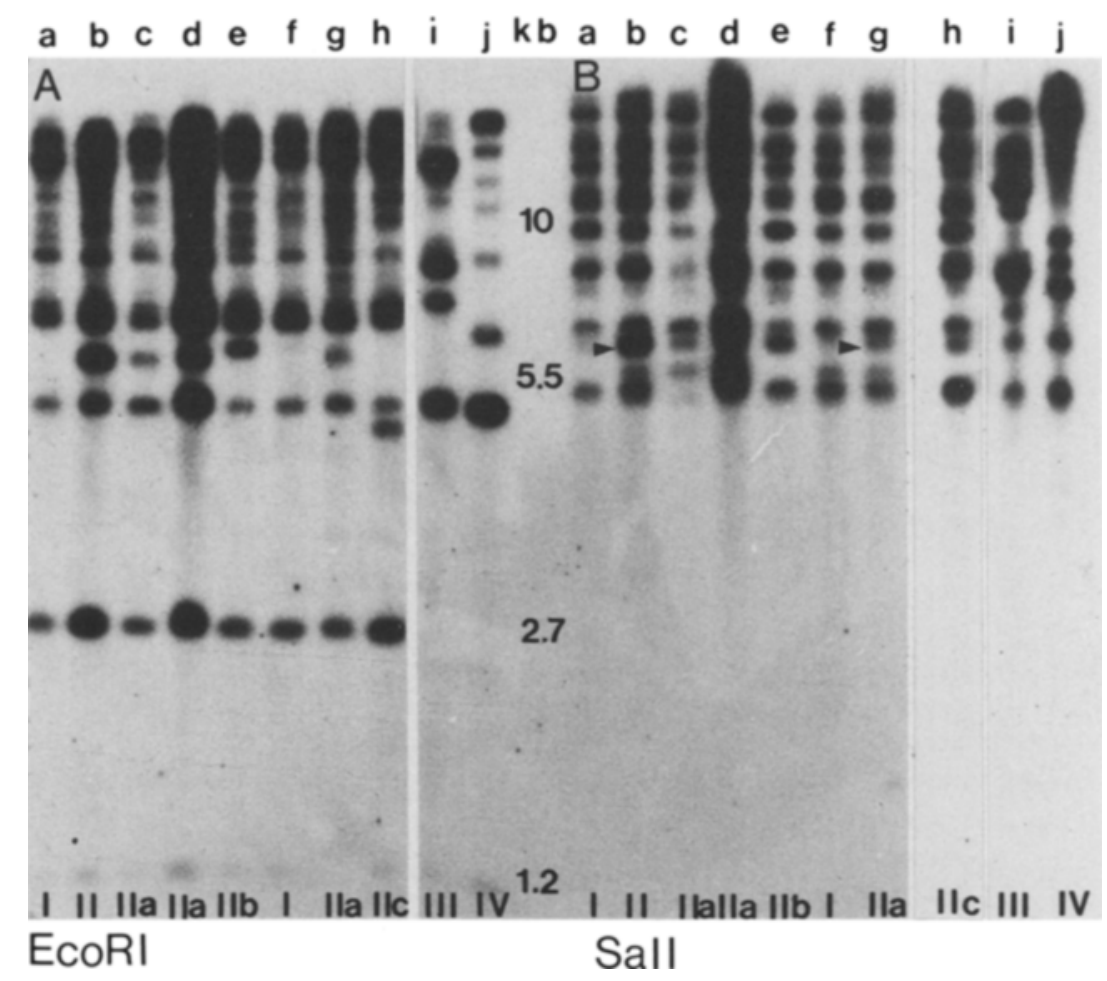

Figure 2. EcoRI and SalI restriction endonuclease fragment patterns (RFLPs) of ten strains which all have been used as bottom fermenting strains. Panel A: Southern blots of EcoRI digestions, panel B: Southern blots of Sall digestions. The DNAs have all been hybridized with the Tyl p14 probe. Lane a: Carlsberg lager strain BK2246, lane b: Tuborg lager strain BK2224, lane c: Pschorr lager strain BK1 101, lane d: Danish lager strain BK2208, e, f, g: German lager strains C83-FP34, C83-FP35, and C83-FP36, lane h: Danish lager strain BK2236, lane i: S. carlsbergensis AJL248 bottom fermenting strain No. I (HANSEN), lane j: S. monacensis CBS1503 bottom fermenting strain No. II (HANSEN). Roman numbers at the bottom of the lanes indicate the pattern designation.

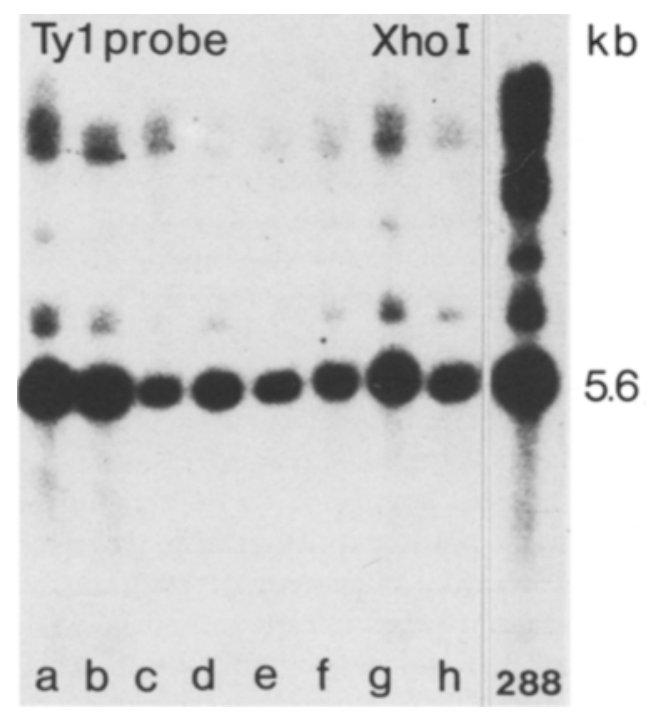

Figure 3. Xho I restriction endonuclease fragment patterns of Southern blots from nine strains hybridized with the probe $T y l \mathrm{pl}$. Lanes a to $\mathrm{h}$ contain DNAs from bottom fermenting strains while lane 288 corresponds to DNA isolated from the $S$. cerevisiae genetic standard strain S288C. Lane a: Carisberg lager strain BK2246, lane b: Tuborg lager strain BK2224, lane c: Pschorr lager strain BK 1101 , lane d: Danish lager strain BK2208, lanes e, f, g: German lager strains C83-FP34, -FP35, and FP36, lane h: Danish lager strain BK2236 and lane 288: standard strain S288C. The nine strains contain a dominating $5.6 \mathrm{~kb}$ fragment comprising the whole $T y$ element including the two flanking $\delta$-sequence halves. 

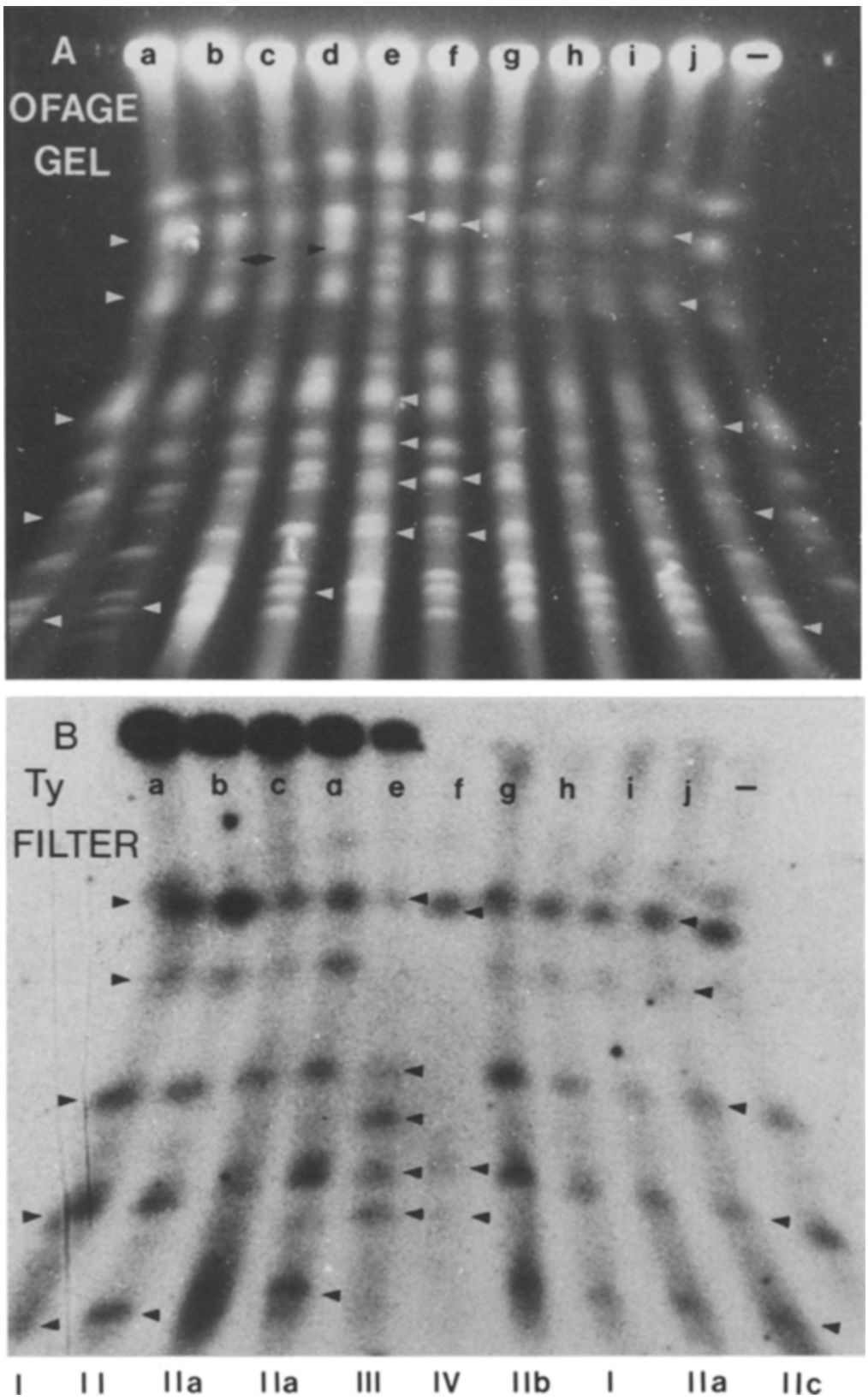

Figure 4. Electrophoretic karyotypes of ten bottom fermenting strains. Panel A: Agarose gel of the separated chromosomes. Panel B: Southern filter hybridized with the probe $T y 1$ p14. Lane a: Carlsberg lager strain BK2246, lane b: Tuborg lager strain BK2224, lane c: Danish lager strain BK2208, lane d: Pschorr lager strain BK1 101, lane e: S. carlsbergensis No. I C84 - AJL248, lane f: S. monacensis CBS1503, lane g: German lager strain C83 - FP34, lane h: German lager strain C83 - FP35, lane i: German lager strain C83 - FP36, lane j: Danish lager strain BK2236. The eight lager strains contain five chromosomal bands which hybridize to the $T y l$ pl4 probe, while S. carlsbergensis C84 - AJL248 contains five and S. monacensis CBS1503 three bands. Two of the bands in the latter two strains are shared by the lager strains, while a third band is also found in the old Pschorr bottom fermenting strain, but not present in the lager brewing strains. Roman numerals below panel 4B correspond to the $T y$ restriction endonuclease patterns in the ten bottom fermenting strains. The chromosomal separations were carried out with a pulsetime of 50 seconds, a constant current of $200 \mathrm{~mA}$ in a $1 \%$ agarose gel containing $0.5 \times \mathrm{TBE}$ buffer. The electrophoresis was run for 18 hours at $8-12^{\circ} \mathrm{C}$. 
ly than the two neighbouring fragments (Figure 2 , lanes $\mathrm{c}$, d) while in pattern IIb the $5.5 \mathrm{~kb}$ EcoRI fragment migrates slower (Figure 2, lane e). Pattern IIa is found in 8 strains and IIb in 2 strains of the present sample (Tables I and IV). The fourth variant IIc is characterised by the presence of a $4.7 \mathrm{~kb}$ EcoRI fragment hybridizing to $T y$ (Figure 2, lane $\mathrm{h}$ ) and has so far only been detected in one strain.

Southern blots of the DNA of the two bottom fermenting clones established by E. CHR. HANSEN (25) as Unterhefe No. I (S. carlsbergensis) and Unterhefe No. II (S. monacensis) probed with $T y$ are given in Figure 2, lanes $i$ and $\mathrm{j}$. The EcoRI and Sall patterns of these two strains are different from each other as well as from the presently used bottom fermenting strains. Their patterns have therefore been designated as III and IV. It is of considerable interest that these two strains are so different in their $T y$ element locations from bottom fermenting strains presently in use. One wonders if the latter have been derived by $T y$ transposition (9). Three $\mathrm{S}$. carlsbergensis (Unterhefe No. I) isolates, namely AJL248, CBS1513, and NCYC396 have been investigated (Table IV). Their $T y$ patterns are identical. The isolate of S. monacensis (Unterhefe No. II) is that kept as clone CBS1503.

The $T y$ element of $\mathrm{S}$. cerevisiae contains a unique Xho I restriction site in the flanking $\delta$-sequences (direct repeats) yielding a $5.6 \mathrm{~kb}$ element $(19,20)$. In Figure 3 the Southern blots of the Xho I digested DNAs of 8 bottom fermenting strains have been probed with the $T y l$ p 14 nick translated fragment. They all contain a $5.6 \mathrm{~kb}$ fragment as the most prominent hybridizing fragment, irrespective of whether their DNA gives restriction fragment patterns I or II. Closely similar amounts of DNA isolated from the strains have been loaded in the slots of the gel in Figure 3. The $\mathrm{S}$. cerevisiae genetic standard strain 288 DNA hybridizes much more heavily to the probe than the DNAs from the bottom fermenting strains. Further studies are necessary to determine if this is due to copy number or differing homology.

\subsubsection{Electrophoretic karyotypes of bottom fermenting strains obtained by $O F A G E$ separation}

In Figure 4 are presented the karyotypes of ten bottom fermenting strains (lanes a to j). In panel $A$ are shown the separated chromosomes of the strains stained with ethidium bromide, while panel B contains the autoradiogram of the corresponding Southern filter hybridized with the probe $T y 1 \mathrm{p} 14$. Eight of the strains (a-d, g-j) have almost identical karyotypes, with only small differences in the mobility of a few of the longest chromosomes (black arrow heads in Figure 4A). Clearly different karyotypes are obtained from S. carlsbergensis C84 - AJL248 (lane e), and S. monacensis CBS1503 (lane f) i.e., the bottom fermenting strains No. I and No. II by E. CHR. HANSEN (25). The same five chromosomal bands of the 8 lager strains hybridize to the probe $T y 1$ p14 (Figure 4B). Since the $T y l$ p14 probe does not hybridize with delta sequences each hybridizing band in Figure 4B corresponds to one or more complete $T y$ elements and the lowest number of $T y$ elements is five. S. carlsbergensis C84-AJL248 contains five chromosome bands with Tyelements, two of which have a different mobility than in modern bottom fermenting strains. S. monacensis CBS1503 reveals only three $T y$ containing chromosome bands two of which have the same mobility as chromosomes with $T y$ elements in lager strains. The third chromosome band has a mobility comparable to one of the chromosomes with $T y$ elements in C84-AJL248.

\subsection{Analysis of hybrid bottom fermenting strains}

The $T y$ elements and the nuclear gene $L E U 2$ on chromosome III are useful markers in breeding of new bottom fermenting strains. In Figure 5, panels A, B, and C are shown Southern blots of DNA from the Carlsberg and Tuborg lager strains together with those from 14 hybrids listed in Table II. The hybrids are produced by mating of meiotic segregants expressing mating type. The LEU2 gene is located on chromosome III as is the mating type locus. It can be seen in Figure 5A that the SalI fragments III and IV hybridizing to the $L E U 2$ probe in the parent strains $(\mathrm{a}, \mathrm{b})$ 
M. B. PEDERSEN: DNA polymorphisms in yeast. III

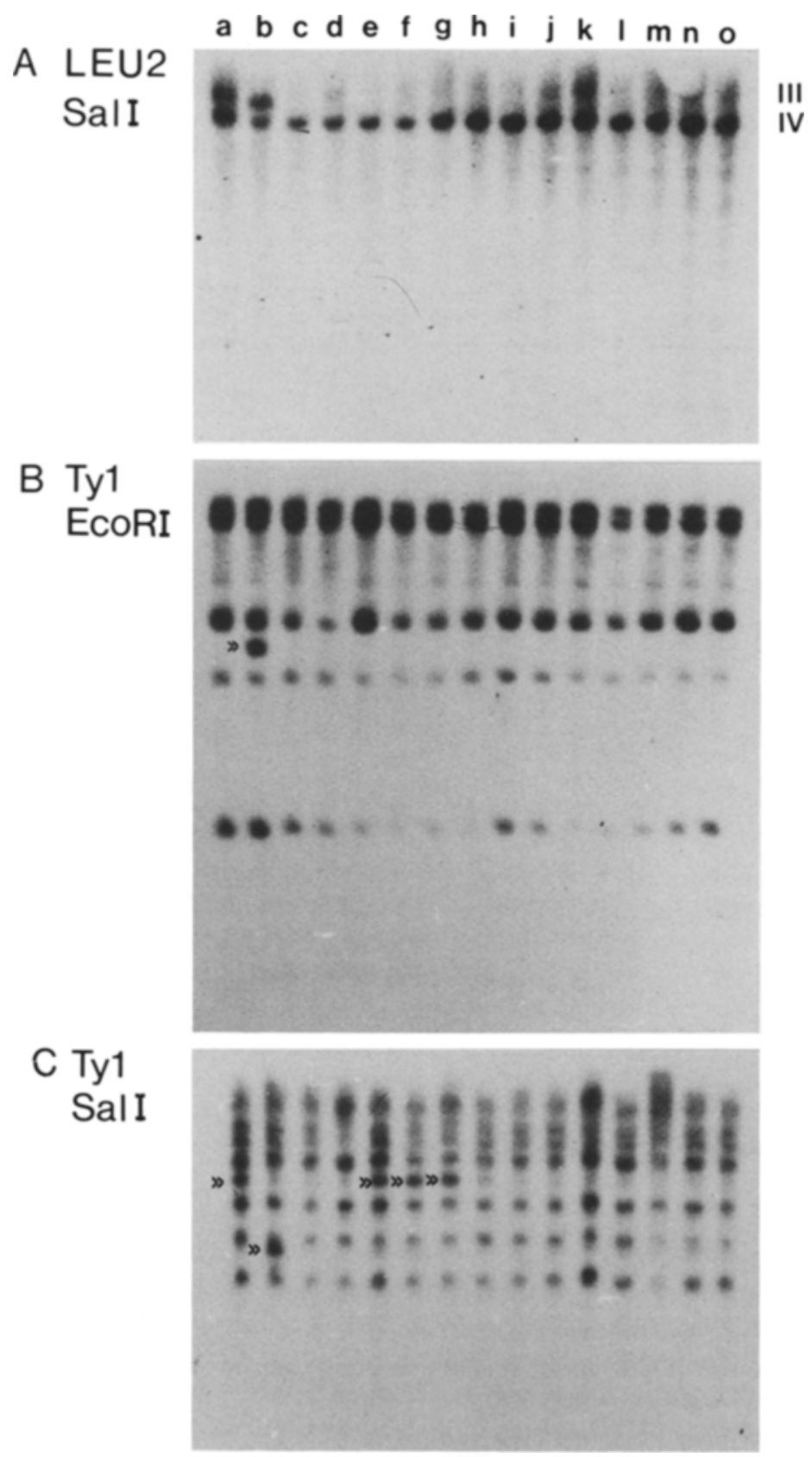

Figure 5. Restriction endonuclease fragment patterns of 15 bottom fermenting strains probed with labelled fragment containing the $L E U 2$ gene and the Ty element. Panel A: SalI digested DNAs hybridized with the $L E U 2$ probe. Panels B and C: EcoRI and Sall digested DNAs hybridized with $T y 1$ p14. Strain a: Carlsberg lager strain BK2246, strain b: Tuborg lager strain BK2224, strain c: C84 - CG 193 hybrid of spore clones from Carlsberg times and spore clones from Tuborg, strain d: C84 - CG1 192 hybrid of spore clone from Carlsberg times spore clones from Tuborg, strains e to o: hybrids of Carlsberg spore clones, strain e: C81 - CG 323, strain f: C81 - CG364, strain g: C81 - CG353, strain h: C81 - CG345, strain i: C81 - CG324, strain j: C81 - CG314, strain k: C82 - CG595, strain 1: C81 - CG285, strain m: C81 - CG286, strain n: C81 - CG287, and strain o: C81 - CG288. Differences in Ty patterns in panels $B$ and $C$ are pointed out by double arrow heads " $>>$ ". 
Table II. Restriction endonuclease fragment patterns of the $L E U 2$ gene and $T y$ elements in two bottom fermenting strains and hybrids of meiotic segregants from these strains. The Southern blots are given in Figure 5. LEU2 fragments IIIw+IV indicates that III hybridizes much weaker than IV, which is most likely due to differences in gene doses of $L E U 2$ III and $L E U 2$ IV. Ty SalI pattern I $\left(10 \mathrm{~kb}^{\prime \prime}\right)$ indicates that the $10 \mathrm{~kb}$ fragment in this pattern hybridizes weakly compared to the pattern in the parent strain.

\begin{tabular}{|c|c|c|c|c|c|}
\hline \multirow[t]{2}{*}{ Restriction pattern: } & \multirow[t]{2}{*}{$\begin{array}{l}L E U 2 \\
\text { fragments }\end{array}$} & \multicolumn{2}{|c|}{$\begin{array}{c}T y \\
\text { patterns }\end{array}$} & \multirow[t]{2}{*}{$\begin{array}{l}\text { Figure } 5 \\
\text { lane }\end{array}$} & \\
\hline & & EcoRI & SalI & & \\
\hline Parental strains: & & & & & Source: \\
\hline BK2246 & III+IV & $\mathbf{I}$ & I & $\mathrm{a}$ & Carlsberg lager strain \\
\hline BK2224 & III+IV & II & II & $\mathrm{b}$ & Tuborg lager strain \\
\hline \multicolumn{6}{|l|}{ Hybrid strains: } \\
\hline \multicolumn{6}{|l|}{$\begin{array}{l}\text { Carlsberg } \times \text { Tuborg } \\
\text { spore clones: }\end{array}$} \\
\hline C84-1193 & IV & I & $I\left(10 \mathrm{~kb}^{\omega}\right)$ & $\mathrm{c}$ & C. GJERMANSEN \\
\hline C84-1192 & IIIw+IV & I & I $\left(10 \mathrm{~kb}^{\mathrm{w}}\right)$ & d & $“$ \\
\hline \multicolumn{6}{|l|}{$\begin{array}{l}\text { Carlsberg } \times \text { Carlsberg } \\
\text { spore clones: }\end{array}$} \\
\hline C81 - CG323 & IV & $\mathbf{I}$ & I & e & C. GJERMANSEN \\
\hline C $81-C G 364$ & IV & I & I & $\mathrm{f}$ & “ \\
\hline $\mathrm{C} 81-\mathrm{CG} 353$ & IV & 1 & I & $\mathrm{g}$ & “ \\
\hline C81-CG345 & IV & I & I $\left(10 \mathrm{~kb}^{\mathrm{w}}\right)$ & $\mathrm{h}$ & “ \\
\hline $\mathrm{C} 81-\mathrm{CG} 324$ & IV & $\mathbf{I}$ & I " & $\mathrm{i}$ & “ \\
\hline C81-CG314 & IIIw+IV & I & I “ & $\mathrm{j}$ & “ \\
\hline C82 - CG595 & “ & I & I “ & $\mathrm{k}$ & “ \\
\hline C81-CG285 & “ & I & I $\cdots$ & 1 & “ \\
\hline $\mathrm{C} 81-\mathrm{CG} 286$ & “ & I & I “ & $\mathrm{m}$ & “ \\
\hline C81 - CG287 & “ & I & I “ & $\mathbf{n}$ & “ \\
\hline C81-CG288 & “ & $\mathbf{I}$ & I “ & 0 & “ \\
\hline
\end{tabular}

segregate independently from each other. Thus 6 hybrids have inherited only fragment IV from the parents (lane c, e-i). The other hybrids contain both fragments, but only hybrid C82CG595 contains the two fragments in similar gene dosages (lane $\mathrm{k}$ ).

The varying proportions of fragments III and IV signify different copy numbers of the two or more types of chromosomes III present in the lager strains. The Tyl hybridization patterns distinguish the Carlsberg lager strain from its Tuborg counterpart (Figure 5B and C, lanes a and b). The $5.5 \mathrm{~kb}$ EcoRI and Sall fragments diagnostic for the Tuborg strains have not been transmitted to the Carlsberg $\times$ Tuborg hybrids (Figure 5, lane c,d). The strongly hybridizing (10 kb Sall) fragment of the Carlsberg lager strain has been inherited only to three hybrids among the 11 Carlsberg $\times$ Carlsberg hybrids (Figure $5 \mathrm{C}$, lanes $\mathrm{e}, \mathrm{f}, \mathrm{g}$ ). It thus is evident that the diagnostic $T y$ elements for the Carlsberg and Tuborg lager strains are inherited independently of one another.

\subsection{Molecular analyses of top fermenting strains}

\subsubsection{LEU2 Sall fragment patterns}

Six $L E U 2$ Sall fragment patterns have been detected among the $12 \mathrm{~S}$. cerevisiae strains listed in Table III. The Scandinavian strains BK3300, BK3302, BK3305, and BK3313 contain SalI fragments II and III together (Figure 6, lanes f, $g$, $\mathrm{i}, \mathrm{k}$ ), while strains of British origin C82-FP1, 
Table III. Restriction endonuclease fragment patterns found in ale strains, designated S. cerevisiae. Patterns of restriction endonuclease fragments hybridizing to the $0.9 \mathrm{~kb} \mathrm{3}$ 'EcoRI - SalI fragment of the $L E U 2$ gene from S. cerevisiae strain S288C. $T y$ pattern: Restriction fragment patterns of $T y$ elements hybridizing to the $\mathrm{S}$. cerevisiae Tyl p14 probe.

\begin{tabular}{lllll}
\hline Strain: & $\begin{array}{l}\text { LEU2 } \\
\text { fragments }\end{array}$ & $\begin{array}{l}\text { Ty } \\
\text { pattern }\end{array}$ & $\begin{array}{l}\text { Figure 6 } \\
\text { lane }\end{array}$ & Source: \\
\hline C82-FP1 & I+II+III & FP1 & a & Malta \\
C82-FP10 & I+III & FP10 & b & Canada \\
C82-FP15 & I+II+III & FP1 & c & Great Britain \\
C82-FP16 & I+II+III & FP1 & d & Great Britain \\
C82-FP17 & 6 kb+III & FP17 & e & Great Britain \\
BK3300 & II+III & BK3300 & f & Denmark, Ceres 1920 \\
BK3302 & II+III & BK3300 & g & Denmark, Horsens 1932 \\
BK3304 & I+II & BK3304 & h & Great Britain, WHITBREAD 1937 \\
BK3305 & II+III & BK3300 & i & Denmark, Maribo 1945 \\
BK3331 & 4 kb+III & BK3331 & j & Great Britain, St. Austel Brewery, 1966 \\
BK3313 & II+III & BK3313 & k & Sweden, Stockholms Bryggerier, 1949 \\
\hline
\end{tabular}

C82-FP15, and C82-FP16 like the type strain for the species Saccharomyces cerevisiae CBS 1171 carry three SalI fragments, namely fragments I, II, and III (Figure 6, lanes a, c, and d). C81-FP10 carries SalI fragment I and III, BK 3304 contains SalI fragments I and II, while BK3331 and C82-FP17 contain a unique fragment together with fragment III. Since the fragments I, II, and III are found in all possible combinations it is likely that they represent different $L E U 2$ genes and thus different chromosomes.

\subsubsection{Ty element patterns in S. cerevisiae top fermenting strains}

Close relationship between the Danish ale strains is uncovered by both EcoRI and Sall digested DNAs in Figure 6, panels B and C. Figure 6, panel B, lanes $\mathrm{f}, \mathrm{g}$, and $\mathrm{i}$ contain DNA from the strains BK3300, BK3302, and BK3305. Their EcoRI fragment patterns are identical, but BK3305 contains an additional SalI fragment when compared to BK3300 and BK3302 (Figure 6, panel C, strain i, marked by arrowhead). The Swedish strain BK3313 is different from the Danish and other strains both in EcoRI and SalI digestions probed with the $T y$ element (Figure 6, panels B and C, lane k). The strains of British origin C82-FP1, -FP15, -FP16, -FP17, and BK3304 have several hybridizing fragments in common both when digested with EcoRI and Sall (Figure 6, panels B and C, lanes a, c, d, e, and h). The two strains C82-FP15 and C82-FP16 seem to be almost identical while C82-FP1 shows close similarity to both strains. The similar EcoRI fragments are indicated by arrowheads (Figure 6, panel B, lanes a, $\mathrm{c}$ and d). The strain C82-FP17 seems to have a unique EcoRI and SalI fragment pattern (Figure 6, lane e). Also the two strains C82-FP10 and BK3331 have unique $T y$ patterns which show little similarity to the other patterns (Figure 6, panels B and $C$, lanes $b$ and $j$ ).

\subsection{The RDN1, HIS4, LEU 2, and Ty genes in different species of Saccharomyces and Zygosaccharomyces}

3.4.1. Zygosaccharomyces fermentati

Zygosaccharomyces fermentati (CBS4506) has previously been included in the genus Saccharomyces as S. montanus (6). An analysis of the DNA of this species with regard to the RDNI, $H I S 4$, and $T y$ genes revealed the following (Figure 7): Probing the Southern blot of the EcoRI restriction fragments with the pY $1 \mathrm{rA} 12$ plasmid containing $R D N I$ form II from S. cerevisiae (46) resulted in two major hybridizing fragments with sizes of 1.8 and $3.4 \mathrm{~kb}$ (Figure 7, lane a) in contrast to the three major EcoRI bands of $2.8 \mathrm{~kb}, 2.4 \mathrm{~kb}$, and $1.95 \mathrm{~kb}$ found in cerevisiae (lane e). While Sall does not cut the $R D N 1$ casettes in both species the restriction endonuclease HindIII digest the $R D N 1$ region in 

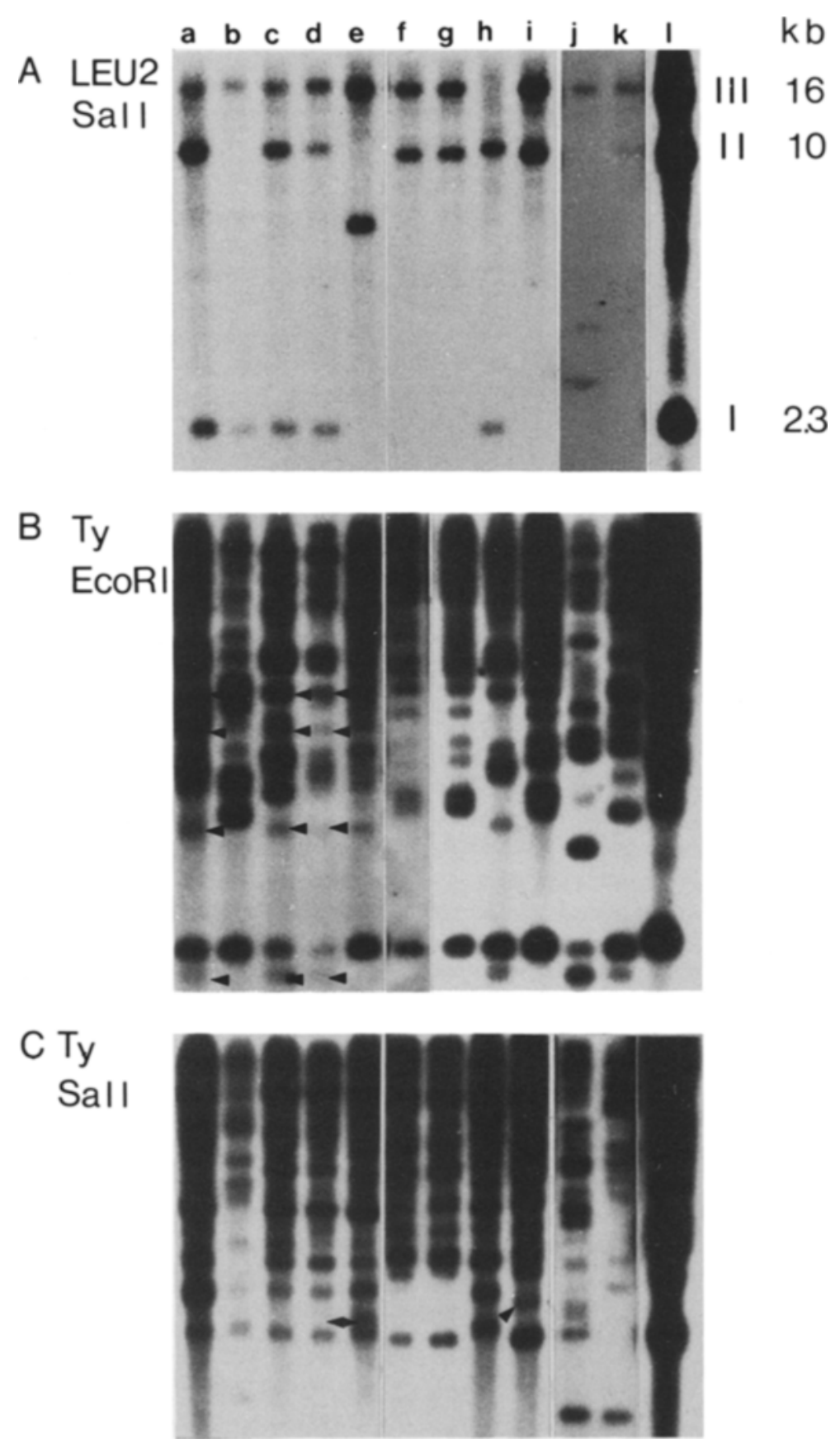

Figure 6. Analyses of $12 \mathrm{~S}$. cerevisiae top fermenting strains. Panel A: Southern blots of the SalI restriction fragment patterns of the 12 strains probed with the $L E U 2$ fragment. Panels B and C: Southern blots probed with the Ty element where panel B contains EcoRI digested DNAs and panel C contains Sall digested DNAs. Strain a: C82 FP1 (Malta), strain b: C82 - FP10 (Canada), strain c: C82 - FP15 (Great Britain), strain d: C82 - FP16 (Great Britain), strain e: C82 - FP17 (Great Britain), strain f: Danish top fermenting strain BK3300, strain g: Danish top fermenting strain BK3302, strain h: British top fermenting strain BK3304, strain i: Danish top fermenting strain BK3305, strain j: British top fermenting strain BK3331, strain k: Swedish top fermenting strain BK3313, and strain 1: S. cerevisiae type strain CBS1171. 

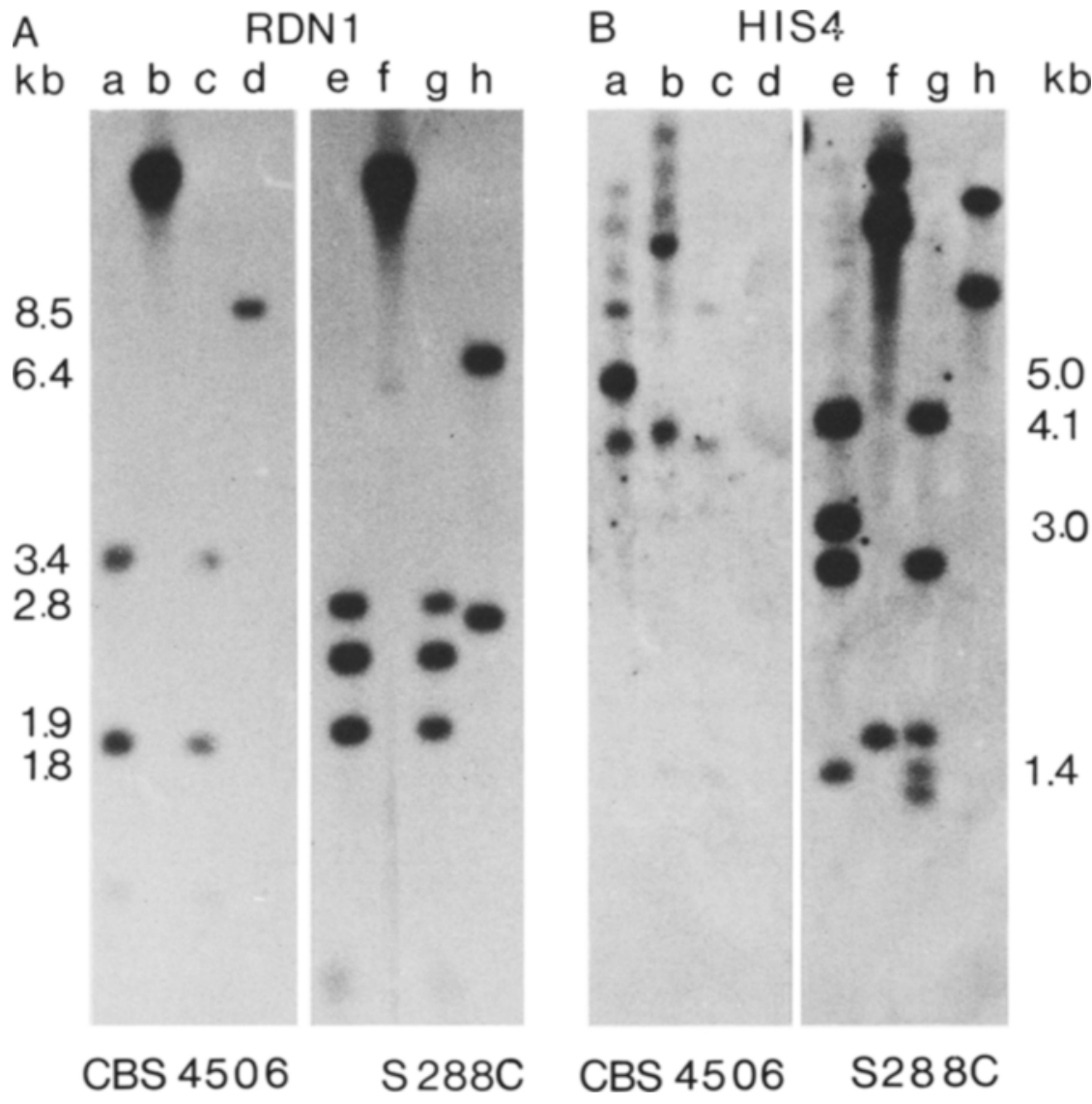

Figure 7. Restriction endonuclease fragment patterns of $R D N 1$ and $H I S 4$ in the two strains Zygosacch. fermentati CBS4506 (formerly S. montanus) and S. cerevisiae S288C genetic standard strain. Panel A: Extracted DNAs hybridized with the probe pYlrA 12 containing RDN1 form II from S, cerevisiae. Panel B: Extracted DNAs hybridized with the HIS4 probe pC503. Lanes a and e: DNA digested by EcoRI, lanes b and f: DNA digested by SalI, lanes $\mathrm{c}$ and $\mathrm{g}$ : DNA digested by both EcoRI and Sall, and lanes $\mathrm{d}$ and $\mathrm{h}$ : DNA digested by HindIII. Fragment sizes in thousand of basepairs (kb).

such a way that one fragment $(8.5 \mathrm{~kb})$ is obtained in Zygosaccharomyces and two (2.6 kb and 6.4 $\mathrm{kb}$ ) in cerevisiae (lanes $d, \mathrm{~h}$ ).

Also the HIS4 gene region probed with plasmid pC503 gives distinct restriction fragment patterns when EcoRI, Sall, and HindIII are used to generate the fragments (Figure 7, panel B). Finally, no hybridization was obtained if the nick translated $T y l \mathrm{p} 14$ probe from S. cerevisiae was tested on the DNA digested with restriction enzymes. It is obvious that Zygosaccharomyces fermentati is distantly related to $S$. cerevisiae.

\subsubsection{The Saccharomyces cerevisiae group}

The characteristics of this group of species is set out in Table IV. This group is monomorphic with regard to the HIS4 region. All members have the pattern I which is examplified by Figure 8 , lane a. Fifteen of the accessions have the $R D N I$ gene form I, while the $\mathrm{S}$. cerevisiae type strain CBS1 171 (a top fermenting brewers yeast) has form II. With regard to the LEU2 gene region the accessions are either homozygous or heterozygous for the Sall restriction fragments I (2.3 kb) II (ca. $10 \mathrm{~kb}$ ) and/or III (ca. $16 \mathrm{~kb}$ ). Four 
Table IV. Characteristics of type strains from ATCC, CBS, NCYC and Danish lager strain BK2208 and wild yeast strains from the brewery environment. The strain C84 - AJL248 is the motherstrain for both CBS1513 and NCYC396. All three strains are clones of the authentic S. carlsbergensis bottom fermenting strain No. I by E. CHR. HANSEN (1908) ref. (25).

\begin{tabular}{|c|c|c|c|c|c|c|c|}
\hline Strain: & & $D N I$ & HIS4 & $L E U 2$ & \multicolumn{3}{|l|}{ Ty pattern } \\
\hline \multicolumn{8}{|l|}{ S. cerevisiae group: } \\
\hline S. cerevisiae & CBS 1171 & II & I & $\mathrm{I}+\mathrm{II}+\mathrm{III}$ & \multicolumn{3}{|l|}{ unique } \\
\hline S. cerevisiae & ATCC4132 & I & $\mathbf{I}$ & III & \multicolumn{3}{|l|}{ unique } \\
\hline S. cerevisiae & C81-1537 & I & I & I & \multicolumn{3}{|l|}{ unique } \\
\hline S.(carlsbergensis) & ATCC9373 & I & I & III & \multicolumn{3}{|l|}{9373} \\
\hline S.(carlsbergensis) & ATCC 10596 & I & I & III & \multicolumn{3}{|l|}{9373} \\
\hline S. capensis & CBS2247 & I & I & III & \multicolumn{3}{|l|}{ n.d. } \\
\hline S. chevalieri & CBS400 & I & I & II+III & \multicolumn{3}{|l|}{ unique } \\
\hline S. diastaticus & CBS1782 & I & I & I & \multicolumn{3}{|l|}{1782} \\
\hline S. diastaticus & ATCC28338 & I & 1 & I & \multicolumn{3}{|l|}{1782} \\
\hline S. ellipsoideus & BK4479 & I & I & III & \multicolumn{3}{|l|}{ unique } \\
\hline S. norbensis & ATCC16041 & I & I & I & \multicolumn{3}{|c|}{ no hybridization at $60^{\circ} \mathrm{C}$} \\
\hline S. odessa & BK4410 & I & I & unique & \multicolumn{3}{|c|}{ unique } \\
\hline \multirow[t]{4}{*}{ S. spec. } & C82-1684 & I & $\mathrm{I}$ & unique & \multicolumn{3}{|l|}{ unique } \\
\hline & C82-1685 & I & I & 1685 & \\
\hline & $\mathrm{C} 82-1686$ & I & I & unique & \multicolumn{3}{|l|}{ unique } \\
\hline & $\mathrm{C} 82-1687$ & I & I & 1685 & \multicolumn{3}{|l|}{1685} \\
\hline \multicolumn{8}{|c|}{ S. carlsbergensis group: } \\
\hline S. carlsbergensis & BK2208 & II & I+II & III+IV & \multicolumn{3}{|l|}{ IIa } \\
\hline S. carlsbergensis I & C84-AJL248 & III & I+IIa & III+IV & \multicolumn{3}{|l|}{ III } \\
\hline S. carlsbergensis I & CBS1513 & III & I+IIa & $\mathrm{III}+\mathrm{IV}$ & \multicolumn{3}{|l|}{ III } \\
\hline S. carlsbergensis I & NCYC396 & III & I+IIa & III + IV & \multicolumn{3}{|l|}{ III } \\
\hline S. monacensis II & CBS 1503 & III & II & IV & \multicolumn{3}{|l|}{ IV } \\
\hline \multicolumn{8}{|l|}{ S. bayanus group: } \\
\hline S. bayanus & CBS380 & III & II+III & IV & \multicolumn{3}{|c|}{ no hybridization at $60^{\circ} \mathrm{C}$} \\
\hline S. bayanus & NCYC374 & III & II+III & IV & “ $\quad \cdots$ & * & “ \\
\hline S. pastorianus & ATCC12752 & III & II+III & IV & “ & “ & “ \\
\hline \multicolumn{8}{|l|}{ S. uvarum group: } \\
\hline S. inusitatus & CBS1546 & III & III & IV & “ & “ & $"$ \\
\hline S. uvarum & C81-1511 & III & III & IV & $"$ & “ & $“$ \\
\hline S. validus & BK4404 & III & n.d. & IV & “ & “ & $“$ \\
\hline Zygosaccharomyces & & c.f. & c.f. & & & & \\
\hline fermentati & CBS4506 & Fig.7 & Fig.7 & n.d. & $“$ & “ & $“$ \\
\hline
\end{tabular}

wild yeasts collected in breweries contain 3 different fragment patterns not seen in other species of the group (Figure 8, lanes o-r). A very high degree of polymorphism is evident when the EcoRI restricted DNAs are probed with the $T y$ element (Figure 8, panel C, and Figure 11, lanes $\mathrm{a}, \mathrm{h}, \mathrm{k}$ ). Among the 15 accessions tested 12 different patterns were encountered.

The two ATCC accessions (9373 and 10596) described as S. (carlsbergensis) or (uvarum) fit most closely to the $S$. cerevisiae group (Table IV). Thus they contain $R D N I$ form I and not form III, which is characteristic for the authentic S. carlsbergensis type strains and for $\mathrm{S}$. uvarum. Likewise, they have the typical HIS4 pattern I (Figure 8, lanes $\mathrm{k}$ and $\mathrm{m}$ ) and not the heterozygous patterns I + II of carlsbergensis or the pattern III of S. uvarum. The Ty restriction 


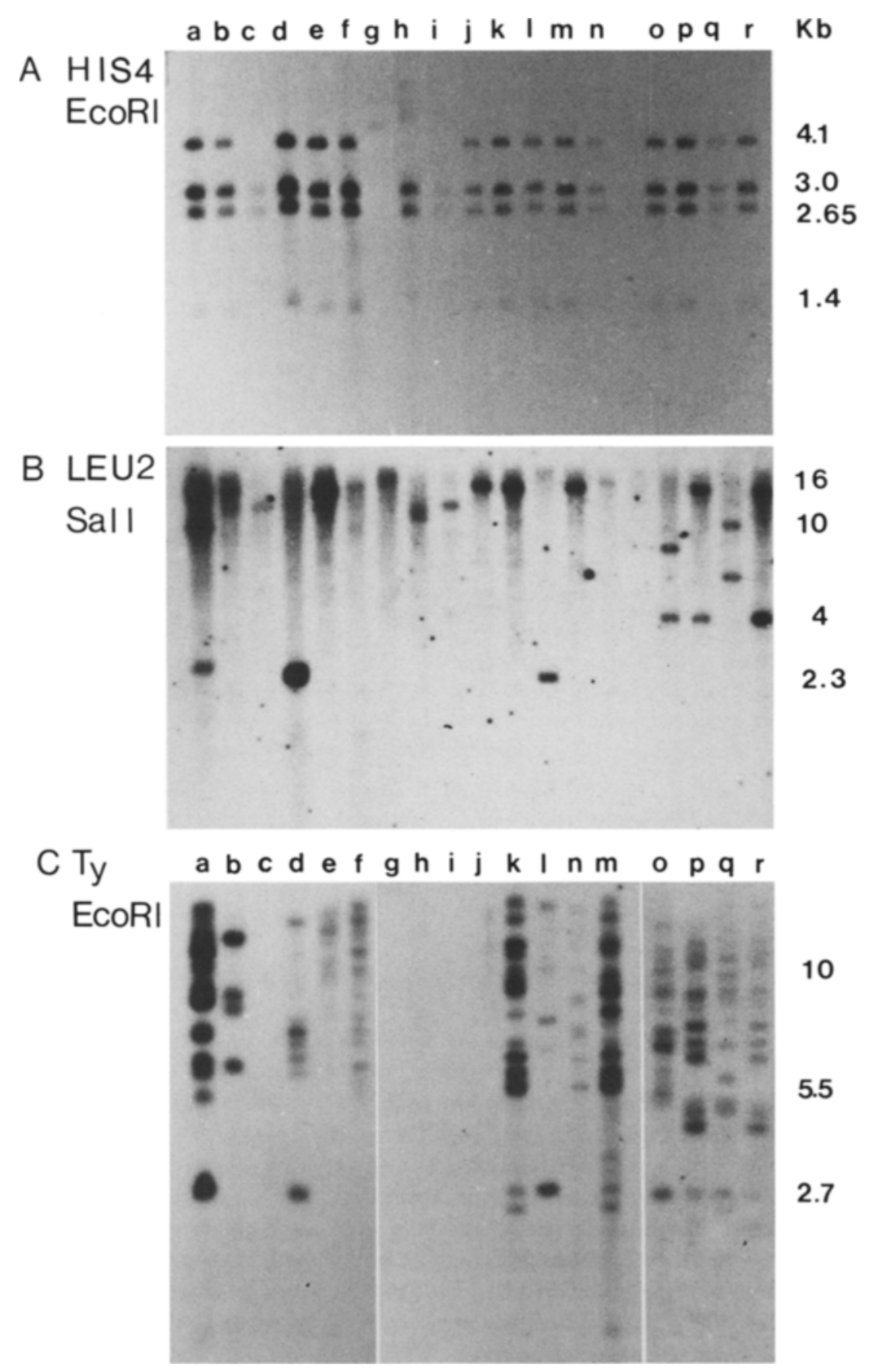

Figure 8. Analyses of fourteen strains from type culture collections and four wild yeast strains from breweries. Panel A: DNAs hybridized with the HIS4 region probe pC503, panel B: DNAs hybridized with the EcoRI - Sall $0.9 \mathrm{~kb}$ LEU2 probe and panel C DNAs hybridized with the $T y 1$ p14 probe. Strain a: S. cerevisiae CBSI 171 , strain b: S. carlsbergensis CBS1513, strain c: S. inusitatus CBS1546, strain d: S. diastaticus CBS1782, strain e: S. capensis CBS2247, strain f: S. chevalieri CBS400, strain g: Zygosacch. fermentati CBS4506, strain h: S. bayanus CBS380, strain i: S. pastorianus ATCC12752, strain j: S. norbensis ATCC 16041, strain k: S.(carlsbergensis) ATCC9373, strain 1: S. diastaticus ATCC28338, strain m: S. carlsbergensis ATCC10596, strain n: S. cerevisiae ATCC41 32, strain o: wild yeast $C 82-1684$, strain p: wild yeast $C 82-1685$, strain q: wild yeast $C 82-1686$, and strain $r$ : wild yeast C82 - 1687. 


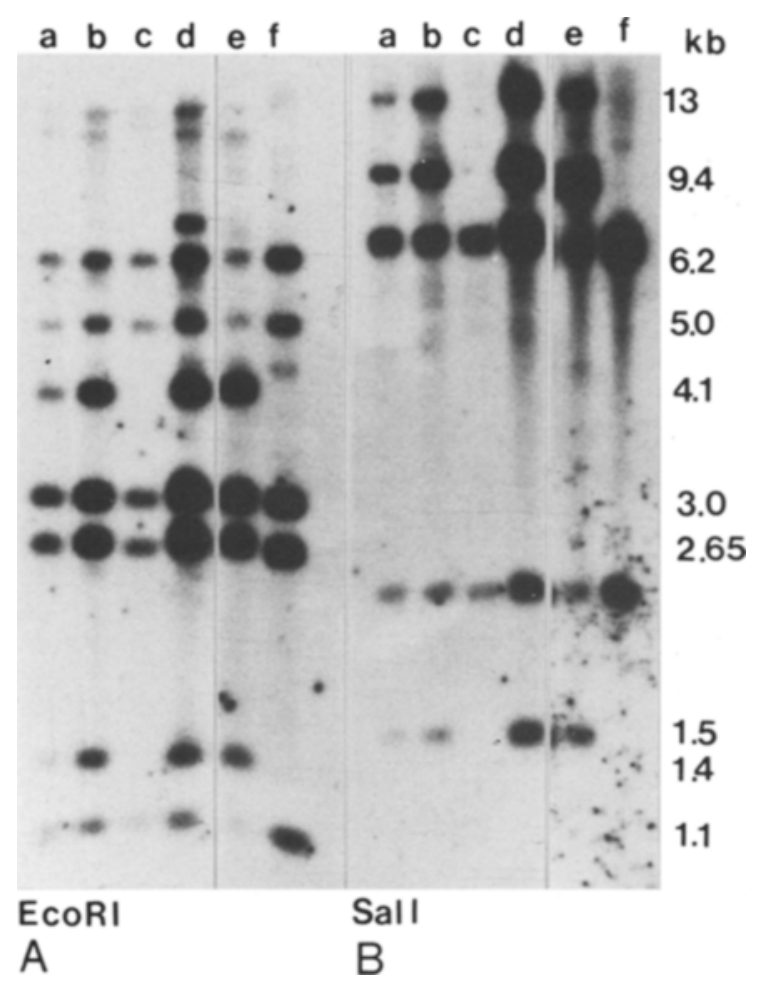

Figure 9. HIS4 fragment patterns of six bottom fermenting strains. Lane a: Carlsberg lager strain BK2246, lane b: Tuborg lager strain BK2224, lane c: Pschorr lager strain BK1101, lane d: Danish lager strain BK2208, lane e: S. carlsbergensis bottom fermenting strain No. I C84 - AJL248, and lane f: S. monacensis CBS 1503 bottom fermenting strain No. II. DNA preparations have been digested by EcoRI (panel A) or Sall (panel B), fragment sizes in thousand of base pairs $(\mathrm{kb})$.

fragment patterns of these two strains are identical (Figure 8, lane $\mathrm{k}$ and $\mathrm{m}$ ), but are unrelatable to the patterns identified for authentic carlsbergensis. The $T y$ element used as probe does not recognise sequences in the uvarum strain (e.g. Figure 11, lane 2). The classification of the two strains ATCC 9373 and ATCC 10596 as S. carlsbergensis or $\mathrm{S}$. uvarum appears unjustified.

The species S. capensis, S. chevalieri, S. diastaticus, and S. ellipsoideus can be distinguished by their unique $T y$ element patterns (Figure 8 , panel C). S. odessa has a unique restriction fragment pattern when probed with nick translated $L E U 2$ and $T y 1$. S, norbensis DNA does not hybridize with the $T y$ element (Figure 8, lane j).

\subsubsection{The Saccharomyces carlsbergensis group}

The type strains of S. carlsbergensis (AJL248, CBS1513, and NCYC396) are characterised by the presence of the RDNI form III, the HIS4 patterns I + Ila (Figure 9, lane e), the LEU2 fragments III + IV (Figure 10, lane g), and the Ty1 pattern III. This strain is the authentic Carlsberg bottom fermenting strain No. I isolated by E. Chr. HANSEN. The other strain HANSEN isolated and designated bottom fermenting strain No. II and subsequently as S. monacensis has the CBS accession number 1503. This clone is characterised by the RDNI form III, apparent homozygosity for HIS4 pattern II (Figure 9, lane f) and the $L E U 2$ fragment IV (Figure 10, lane a). It contains further the $T y$ restriction enzyme fragment pattern IV (Figure 2 , lane $\mathrm{j}$ ). The present day bottom fermenting strains represented by BK2208 in Table IV have

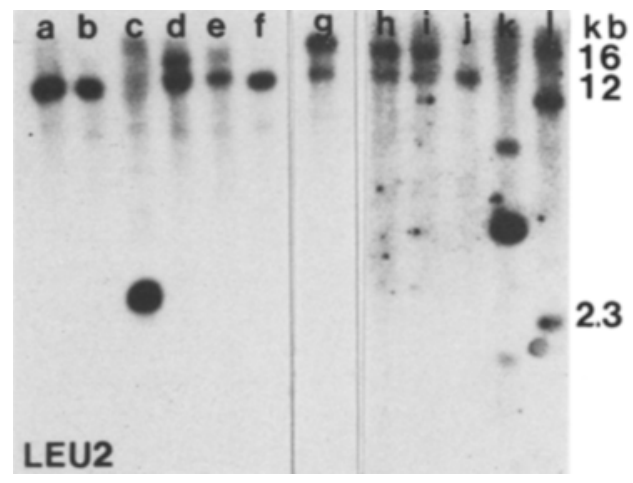

Figure 10. SalI restriction fragment patterns hibridizing to $L E U 2$ in seven strains. The Southern blots of the digested DNA preparations have been probed with the EcoRI - SalI $0.9 \mathrm{~kb} L E U 2$ fragment from $\mathrm{S}$. cerevisiae. Lane a: $S$. monacensis CBS1503, lane $b$ : $\mathbf{S}$. bayanus NCYC374, lane c: genetic standard strain S288C, lane d: Carlsberg lager strain BK2246, lane e: Pschorr lager strain BK1101, lane f: S. uvarum C81 - 1511, and lane g: S. carlsbergensis C84 - AJL248, lane h: lager strain BK2229, lane i: Danish lager strain BK2236, lane j: S. validus BK4404, lane k: S. odessa BK4410, and lane 1: ale strain C82-FP1. Approximate fragment sizes are in thousand of base pairs $(\mathrm{kb})$. 


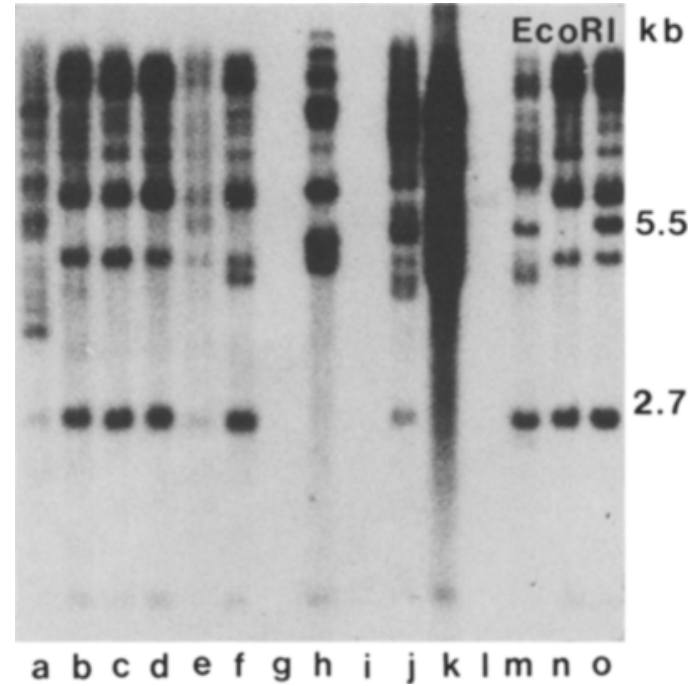

Figure 11. EcoRI restriction endonuclease fragment patterns from 15 yeast strains probed with the labelled Ty element. Lane a: Trappiste ale strain C81 - 1537, lane b: lager strain BK1103, lane c: lager strain BK 1112 , lane d: lager strain BK 1115 , lane e: lager strain BK2229 (low amount of DNA), lane f: lager strain BK2236, lane g: S. validus BK4404, lane h: S. odessa BK4410, lane i: Brettanomyces clausenii BK4420, lane j: S. cerevisiae BK4438, lane $k$ : $S$. ellipsoideus BK4479, lane 1: S. (uvarum/pastorianus) BK4484, lane m: S. spec. BK4499, lane n: Carlsberg lager strain BK2246, and lane o: Tuborg lager strain BK2224. The isolated DNAs have been hybridized with the probe $T y$ p14. Note that the lager strains contain $T y$ patterns I or II, while the other strains exhibit totally different patterns of hybridization with $T y$ or no hybridization at all.

RDNI form II, the HIS4 pattern I + II (Figure 9, lane d), the $L E U 2$ fragment III + IV and the $T y$ pattern La. While the old Pschorr bottom fermenting strain is similar to modern lager strains in several characteristics including karyotype (Figure 4) it shares with S. monacensis apparent homozygosity for the HIS4 pattern II (Figure 9, lanes $\mathrm{c}$ and $\mathrm{f}$ ).

\subsubsection{The Saccharomyces bayanus and uvarum groups}

Both these groups are characterised by the lack of homology between their DNA and the $T y l$ element from S. cerevisiae (Figure 8, lanes $c, h$,
Table IV). Both groups have apparent homozygosity for the $L E U 2$ fragment IV (Figure 8, lanes $\mathrm{c}, \mathrm{h}, \mathrm{i}$, and Figure 10, lanes $\mathrm{b}, \mathrm{f}$, and $\mathrm{j}$ ). $R D N I$ form III, also known in the $S$. carlsbergensis and S. monacensis type strains, are found both in the bayanus and uvarum groups. The HIS 4 probe of S. cerevisiae hybridizes only weakly to the HIS4 genes of bayanus, pastorianus, uvarum, inusitatus, and validus (Figure 8, lanes $\mathrm{c}, \mathrm{h}, \mathrm{i}$ ). S. bayanus and pastorianus are characterised by HIS4 pattern II + III while only III is found in uvarum and its relatives.

\section{DISCUSSION}

The distribution among species of the restriction fragment patterns of RDN1, HIS4, LEU2 genes, and $T y$ elements found in this and previous studies $(40,41,42,43)$ is summarised in the composite diagram of Figure 1. One might argue that the four genetic regions used for deducing the phylogenetic relationships of the species in Figure 1 is too limited, since a taxonomic study should include as many characters as possible. However, the view that $S$. cerevisiae and $S$. uvarum comprise opposite ends of a series of intermediate taxons is further supported by molecular analyses of the $P D C 1$ gene, the $S U C$ gene family, as well as the $T R P 1, T R P 2, T R P 3$, and $T R P 4$ genes $(10,13,55)$. Also DNA reassociation studies are in agreement with the deduction $(8,36,51)$. The $P D C 1$ gene from S. cerevisiae encoding pyruvate decarboxylase has been hybridized to DNA from several Saccharomyces strains (55), and yielded from S. uvarum DNA $P D C I$ restriction endonuclease fragments different from those of S. cerevisiae strains. When the 3' half of S. cerevisiae SUC2 (encoding an invertase) was hybridized to DNA from nine Saccharomyces strains five different $S U C$ restriction endonuclease fragment patterns were seen (13), S. cerevisiae FL100 hybridized with two BglII fragments while a strain designated $S$. carlsbergensis hybridized with three $S$. bayanus showed lower homology to the probe than the other strains investigated (13). S. uvarum strains show both differences in BamHI restriction endonuclease fragment sizes and lower homology to $\mathrm{S}$. cerevisiae $T R P 1, T R P 2, T R P 3$, and $T R P 4$ genes (10). Moreover, the karyotypes of the Saccharomyces strains presented in this 
study and the accompanying paper (44) show clearly that the bottom fermenting strains (lager strains, S. carlsbergensis No. I and S. monacensis) have several chromosome bands in common with each other and S. cerevisiae. S. bayanus, S. pastorianus, and $S$. uvarum are very similar and different from the other groups of strains (44). The fact that it has been very difficult to achieve chromosome transfer from S. bayanus and S. uvarum to $S$. cerevisiae strain K5-5A may indicate considerable biological unrelatedness of these species (44). The weak molecular hybridization intensity of RDNI form II and HIS4 probes from $S$. cerevisiae to DNA from Zygosaccharomyces fermentati reveal the relative large genetic distance between $\mathrm{S}$. cerevisiae and $\mathrm{Z}$. fermentati. That molecular hybridization was possible is probably due to both the redundancy of RDN1 genes (54) and the conservation of coding sequences in the RDN1 and HIS4 genes throughout the Fungi $(33,52,60)$. Large genetic differentiation among the species in the genus Saccharomyces had already been uncovered by WINGE and LAUSTSEN, when they had great difficulties in producing viable offspring from the hybrid between $S$. cerevisiae and $S$. validus (now S. uvarum) (63). Concerning the relationship among brewing strains two features are rather striking, namely the homogeneity of the bottom fermenting strains and the diversity of the top fermenting strains. The homogeneity of the bottom fermenting strains is seen at $R D N 1$, HIS4, LEU2, and $T y$ together with the near identical karyotypes of the lager strains. Even the strains which contain $T y$ patterns I, II, IIa, IIb, and IIc exhibit almost inseparable karyotypes as shown in Figure 4. The Pschorr lager strain BK1101 seems to contain a large chromosome which has different mobility than in the other lager strains. The other bottom fermenting strains which contain deviating karyotypes are S. carlsbergensis No. I and S. monacensis. In contrast to the lager strains a variety of polymorphisms are seen among the top fermenting strains. This is the case for the top fermenting strains of Scandinavian, British, and German origin (this study and $40,41,42,43$ ), especially the LEU2 genes and the Ty elements showing several unique patterns. An explanation for the homogeneity of the bottom fermenting strains and the diversity of the top fermenting strains could be that the top fermenting strains historically have been propagated more or less isolated in individual breweries for centuries, while the bottom fermenting strains have become widespread from a few sources throughout two centuries. It has been established by genetic and molecular analyses that the Carlsberg lager strain contains homoeologous chromosomes originating from two different genomes. The homoeologous chromosomes undergo limited crossover and it can be hypothesized that the lagerstrain is a permanent species hybrid $(26,39$, $61,62)$. One way to introduce new genotypes of brewing strains is to reshuffle the chromosomes of the two or more genomes. Alternatively, mutagenisation of the spore clones from the lager yeast followed by crossing could produce new hybrid strains with the desired brewing properties. Such experiments have been carried out by GJERMANSEN and SigSGaARD (23) and GJERMANSEN (24), and the strains have been tested for brewing performance in a small scale (57). In the first of the two studies a hybrid lager strain was produced from spore clones from the Carlsberg lager strain. The hybrid strain produced lager beer which, in general, was similar to the beer produced by the parental strain, but the new strain seemed to be more flocculent than its parent (24).

\section{ACKNOWLEDGEMENTS}

I wish to thank DITER VON WETTSTEIN and MORTEN KIELLAND-BRANDT for many fruitful and stimulating discussions during the study of the genus Saccharomyces, and I am indebted to Claes Guermansen, Steen Holmberg, MOGENS JACOBSEN (Alfred Jørgensen Laboratories), TORSTEN NilsSON-TIllgren, TOM Petes, Peter Phillppsen, and Poul SigsGAARD for yeast strains and vector harboring $E$. coli strains which have been used throughout the study. I also wish to thank SUSANNE BRUUN for excellent technical assistance and ANNELISE ABEL for figure preparations.

\section{REFERENCES}

1. Adoutte-Panvier, A., J.E. Davies, L. R. Gritz \& B. LITTLEWOOD: Ribosomal proteins of yeast spe- 
cies and their hybrids. Mol. Gen. Genet. 179, 273-283 (1980)

2. Aigle. M.. D. Erbs \& M. Moll: Some molecular structures in the genome of lager brewing yeasts. ASBC Journal 42, 1-7 (1984)

3. Andreadis, A.. Y. -P. Hsu, G. B. Kohlhaw \& P. SCHIMMEL: Nucleotide sequence of yeast LEU2 shows 5 -noncoding region has sequences cognate to leucine. Cell 31, 319-325 (1982)

4. Baharaeen. S. \& H. S. Vishniac: 25S RNA homologies of basidiomycetous yeasts: taxonomic and phylogenetic implications. Can. J. Microbiol. 30, 613-621 (1984)

5. Baichwal, V. R., T. S. Cunningham, P. R. GatZEK \& G. B. KOHLHAW: Leucine biosynthesis in yeast. Curr. Genet. 7, 369-377 (1983)

6. Barnett, J. A., R. W. Payne \& D. YarRow: Yeasts: Characteristics and identification. Cambridge University Press (1983)

7. Bell, G. I., L. J. DeGennaro, D. H.Gelfand, R. J. Bishor, P. Valenzuela \& W. J. RutTer: Ribosomal RNA genes of Saccharomyces cerevisiae. I. Physical map of the repeating unit and location of the regions coding for $5 \mathrm{~S}, 5.8 \mathrm{~S}, 18 \mathrm{~S}$ and $25 \mathrm{~S}$ ribosomal RNAs. J. Biol. Chem. 25, 8118-8125 (1977)

8. Bicknell, J. N. \& H. C. Douglas: Nucleic acid homologies among species of Saccharomyces. J. Bacteriol. 101, 505-512 (1970)

9. Boeke. J. D., D.J.Garfinkel, C. A.STyles \& G. R. FINK: Ty elements transpose through an RNA intermediate. Cell 40, 491-500 (1985)

10. Braus, G., R. Further, F. Prantl, P. NiederBERGER \& R. HUTTER: Arrangement of genes TRP1 and TRP3 of Saccharomyces cerevisiae strains. Arch. Microbiol. 142, 383-388 (1985)

11. Carle, G. F. \& M. V. Olson: Separation of chromosomal DNA molecules from yeast by othogonal-field alternation gel electrophoresis. Nucl. Acid Res. 12, 5647-5664 (1984)

12. Carle, G. F. \& M. V. Olson: An electrophoretic karyotype for yeast. Proc. Natl. Acad. Sci. USA 82, 3756-3760 (1985)

13. CARlson, M. \& D. Botstein: Organization of the SUC gene family in Saccharomyces. Mol. Cell. Biol. 3, 351-359 (1983)

14. Chinault, A. C. \& J. Carbon: Overlap hybridization screening: Isolation and characterization of overlapping DNA fragments surrounding the LEU2 gene on yeast chromosome III. Gene 5, $111-126(1979)$

15. Cramer, J. H., F. W. Farrelly \& R. H. Rownd: Restriction analysis of ribosomal DNA from Saccharomyces cerevisiae. Mol. Gen. Genet. 148, 233-241 (1976)
16. DeCOCK, J. P. \& D. IsERENTANT: Ty hybridisation patterns of yeast and their use for strain identification. Proc. 20th Europ. Brewery Conv. Congr. Helsinki pp. 195-202 (1985)

17. Denhardt, D. T.: A membrane - filter technique for the detection of complementary DNA. Biochem. Biophys. Res. Commun. 23, 641-646(1966)

18. Dobson, M. J., S. M. Kingsman \& A. J. KingsMAN: Sequence variation in the LEU2 region of the Saccharomyces cerevisiae genome. Gene 16, 133139 (1981)

19. Eibel, H., J. Gafner, A. Stotz \& P. Philippsen: Characterization of the yeast mobile element Tyl. Cold Spring Harbor. Symp. Quant. Biol. 45, 609617 (1980)

20. Elder, R. T., T.P.ST. John, D. T.StinchComb, S. SCHERER \& R. W. DAvis: Studies of the transposable element Tyl of yeast. Cold Spring Habor. Symp. Quant. Biol. 45, 581-591 (1980)

21. FINK, G. R: A cluster of genes controlling three enzymes in histidine biosynthesis in Saccharomyces cerevisiae. Genetics 53, 445-459 (1966)

22. Froman, B. E., R. C. Tait \& R. L. Rodriquez: Nucleotide sequence of the 3' terminal region of the LEU2 gene from Saccharomyces cerevisiae. Gene 31, 257-261 (1984)

23. GJermansen, C.\&P. SigsGaARD: Construction of a hybrid brewing strain of Saccharomyces carlsbergensis by mating of meiotic segregants. Carlsberg Res. Commun. 46, 1-11 (1981)

24. Guermansen, $C$ : : Mutagenisis and genetic transformation of meiotic segregants of lager yeast. Carlsberg Res. Commun. 48, 557-565 (1983)

25. HANSEN, E. CHR.: Recherches sur la physiologie et la morphologie des ferments alcooliques. Compt. Rend. Lab. Carlsberg 7, 179-217 (1908)

26. Holmberg, S., J. G. L. Petersen, T. NilssonTillgren \& M. C. Kielland-BRANDT: Molecular characterization of a Saccharomyces plasmid containing the HIS4 gene. Carlsberg Res. Commun. 44, 269-282 (1979)

27. Holmberg, S.: Genetic differences between Saccharomyces carlsbergensis and $\mathrm{S}$. cerevisiae. II. Restriction endonuclease analysis of genes in chromosome III. Carlsberg Res. Commun. 47, 233-244 (1982)

28. Holmes. D. S. \& M. Quigley: A rapid boiling method for the preparation of bacterial plasmids. Anal. Biochem. 114, 193-197 (1981)

29. JeFFreYS, A.J.\&R. A. FlavelL: A physical map of the DNA regions flanking the rabbit $\beta$-globin gene. Cell 12, 429-439 (1977)

30. KEIDING, A. K.: Genetic and molecular characterization of a distiller's yeast. Carlsberg Res. Commun. 50, 95-125 (1985) 
31. KLein, H. L. \& T.D. Petes: Genetic mapping of Ty elements in Saccharomyces cerevisiae. Mol. Cell. Biol. 4, 329-339 (1984)

32. Kurtzman, C. P.: DNA base sequence complementarity and the definition of fungal taxa. Microbiol. Sciences 1, 44-48 (1984)

33. Legerton, T. L. \& C. YanOFsky: Cloning and characterization of the multifunctional his- 3 gene of Neurospora crassa. Gene 39, 129-140 (1985)

34. Maniatis, T., E. F. Fritsch \& J. Sambrook: Molecular cloning. A laboratory Manual. Cold Spring Harbor Laboratory, New York (1982)

35. Martens, F. B., R. van den Berg \& P. A. HarteVELD: DNA fingerprinting of yeast strains. proc. 20th Europ. Brewery Conv. Congr. Helsinki, pp 211-217 (1985)

36. Martini, A. Vaughan \& C. P. Kurtzman: Deoxyribonucleic acid relatedness among species of the genus Saccharomyces sensu stricto. Int. J. Syst. Bacteriol. 35, 508-511 (1985)

37. Montrocher, R: Serological relationships among sporogenous and asporogenous yeasts. Cellular \& Molecular Biology 28, 1-13 (1982)

38. MorTimer, R. K. \& D. SCHLL: Genetic map of Saccharomyces cerevisiae, Edition 9. Microbiol. Rev. 49, 181-212 (1985)

39. Nilsson-Tillgren. T.. C. Giermansen. M. C. KiELland-BRANDT,J.G. L PeTERSEN, \& S. HolmBERG: Genetic differences between Saccharomyces carlsbergensis and $\mathrm{S}$. cerevisiae. Analysis of chromosome III by single chromosome transfer. Carlsberg Res. Commun. 46, 65-76 (1981)

40. Pedersen. M. B.: Fingerprinting of DNA in the identification of yeast. Proc. 19th Europ. Brewery Conv. Congr. London, pp. 457-463 (1983)

41. Pedersen, M. B.: DNA sequence polymorphisms in the genus Saccharomyces I. Comparison of the HIS4 and ribosomal RNA genes in lager strains. ale strains and various species. Carlsberg Res. Commun. 48, 485-503 (1983)

42. Pedersen. M. B.: Brewing yeast identification by DNA fingerprinting. Proc. 20th Europ. Brewery Conv. Congr. Helsinki (1985)

43. Pedersen, M. B.: DNA sequence polymorphisms in the genus Saccharomyces II. Analysis of the genes RDN1, HIS4, LEU2 and Ty transposable elements in Carlsberg, Tuborg and 22 Bavarian brewing strains. Carlsberg Res. Commun. 50, 263272 (1985)

44. Pedersen, M. B.: DNA sequence polymorphisms in the genus Saccharomyces IV. Homoeologous chromosomes III in S. bayanus, S. carlsbergensis and S. uvarum. Carlsberg Res. Commun. 51, 185-202 (1986)

45. Petes, T. D., L. M. Hereford \& K. G. Skryabin:
Characterization of two types of yeast ribosomal DNA genes. J. Bacteriol. 134, 295-305 (1978)

46. Petes. T. D.: Meiotic mapping of yeast ribosomal deoxyribonucleic acid on chromosome XII. J. Bacteriol. 138, 185-192 (1979)

47. Philippsen, P., M. Thomas, R. A. Kramer \& R. W. DAvis: Unique arrangent of coding sequences for 5S, 5. 8S, $18 \mathrm{~S}$ and 25S ribosomal RNA in Saccharomyces cerevisiae as determined by R-loop and hybridization analysis. J. Mol. Biol. 123, 387-404 (1978)

48. Philippsen, P., H. Eibel, J. Gafner \& A. Stotz: Ty elements and the stability of the Saccharomyces cerevisiae genome. In: Gene Expression in Yeast. Proceedings of the Alko Yeast Symposium Helsinki 1983. Ed. by M. Korhola \& E. Väisänen eds. Foundation for Biotechnical and Industrial Fermentation Research 1, pp. 189-200 (1983)

49. Price. C. W.. G. B. Fuson \& H. J. Phaff: Genome comparison in yeast systematics: Delimitation of species within the genera: Schwanniomyces, Saccharomyces, Debariomyces and Pichia. Microbiol. Rev. 42, 161-193 (1978)

50. Rigby, P. W. J., M. Dieckmann, C. Rhodes \& P. BERG: Labeling deoxyribonucleic acid to high specific activity in vitro by nick translation with DNA polymerase I. J. Mol. Biol. 113, 237-251 (1977)

51. Rosini,G., F. Federici, A. E. Vaughan \& A. MarTINI: Systematics of the species of the genus Saccharomyces associated with the fermentation industry. European J. Appl. Microbiol. Biotechnol. 15, 188-193 (1982)

52. Russell. D. J., S. WAGNeR, K. D. Rodland, R. L Feinbaum. J. P. Russell, M. S. Bret-Harte, S. J. Free \& R. L. MetzenberG: Organization of the ribosomal ribonucleic acid in various wildtype strains and wild-collected strains of Neurospora. Mol. Gen. Genet. 196, 275-282 (1984)

53. SChWARTZ, D. C \& C. R. CANTOR: Separation of yeast chromosome-sized DNAs by pulsed field gradient gel electrophoresis. Cell 37, 67-75 (1984)

54. Schwiezer, E., C. MacKechnie \& O. HalvorSON: The redundancy of ribosomal and transfer RNA genes in Saccharomyces cerevisiae. J. Mol. Biol. 40, 261-277 (1969)

55. Seehaus, T.. R. Rodicio, J. Heiniseh, A. AguiLERA, H. D. SCHMITT \& F. K. ZIMMERMANN: Specific gene probes as tool in yeast taxonomy. Curr. Genet. 10, 103-110(1985)

56. Sherman, F., G. R. FinK \& J. R. Hicks: Methods in Yeast Genetics. Cold Spring Harbor Laboratory, Cold Spring Harbor, N. Y. 11724, pp. 61-64(1979)

57. Sigsgaard, P. \& J. N. Rasmussen: Screening of the brewing performance of new yeast strains. 
ASBC Journal 43, 104-108 (1985)

58. SOUTHERN, E. M.: Detection of specific sequences among DNA fragments separated by gel electrophoresis, J. Mol. Biol. 98, 503-517 (1975)

59. Storms, R. K., J. B. MCNeil, P.S. Khandekar, G. AN, J. PARKER \& J. D. Friesen: Chimeric plasmids for cloning of deoxyribonucleic acid sequences in Saccharomyces cerevisiae. J. Bacteriol. 140, 73-82 (1979)

60. Verbeet. M. P., J. Klootwijk, H. van Heerikshuizen, R. Fontijn, E. VReugdenhil \& J. PLANTA: Molecular cloning of the rDNA of Saccharomyces rosei and comparison of its transcription initiation region with that of Saccharomyces carlsbergensis. Gene 23, 53-63 (1983)

61. WeTtSTEIN, D. vON: Emil Christian Hansen Centennial Lecture: from pure yeast culture to genetic engineering of brewers yeast. Proc. 19th Europ. Brewery Conv. Congr. London, pp. 97-120 (1983)
62. Wettstein, D. von, C. Giermansen, S. HolmBerg, M. C. Kielland-Brandt, T. NilssonTIllgren, M. B. Pedersen, J. G. L. Petersen \& P. SIGSGAARD: Genetic engineering in the improvement of brewers yeast. MBAA Tech. Quart. 21, 45-61 (1984)

63. WINGE, Ø.\& O. LAUSTSEN: On 14 new yeast types, produced by hybridization. Compt. Rend. Lab. Carlsberg, Ser. Physiol. 22, 337-352 (1939)

64. Yamazaki, M., S. Goto \& K. Komagata: Comparison of enzymes from strains of wine yeast and their related yeasts on electrophoresis. J. Inst. Enol. Vitic. Yamanashi Univ, 17, 11-19 (1982)

65. YANG, C. A., J LIS \& R. WU: Elution of DNA from agarose gels after electrophoresis. Meth. in Enzymol. 68, 176-182 (1979)

66. YARROW,D.\& T. NAKASE: DNA base composition of species of the genus Saccharomyces. Antonie van Leeuwenhoek 41, 81-88 (1975)

Accepted by E. LUND 